Available online at GSC Online Press Directory

GSC Biological and Pharmaceutical Sciences

e-ISSN: XXXX-XXXX, CODEN (USA): GBPSC2

Journal homepage: https://www.gsconlinepress.com/journals/gscbps

(RESEARCH ARTICLE)

\title{
Parasites associated with Clarias gariepinus (African catfish) from dam, plastic and concrete ponds in Bauchi metropolis, Bauchi State, Nigeria
}

\author{
Udechukwu Chukwunonso Uche*, Panda Sam Mao, Sunday Inusa Danladi and Bello Fatima Adeola \\ Department of Biological Sciences, Abubakar Tafawa Balewa University, Bauchi, Bauchi State, Nigeria.
}

Publication history: Received on 15 January 2018; revised on 14 February 2018; accepted on 16 February 2018

https://doi.org/10.30574/gscbps.2018.2.2.0003

\begin{abstract}
Fish farming is an economic venture to make up the supply of human need of animal protein. Parasitic infections are some of the factors hindering high fish productivity in fish farms. Parasites associated with Clarias gariepinus were detected in Bauchi metropolis. A total of eighteen fishes were sampled, comprising of 6 plastic pond fish, 6 concrete pond fish and 6 dam fish were examined for parasite infestation. The fins, gills and skin of the fishes were examined for ectoparasites, while the lining of the gut lumen and gut contents were examined for endoparasites. Four parasitic species were encountered, these include, 2 protozoan: Trichodina spp., Ichthyophthiriusmultifilis, and 2 Helminthes (cestodes): Diphyllobothrium dendriticum, Diphyllobothrium latum. Ichthyophthirus muftifilis were the most common parasites found in dam and pond samples examined. Of the eighteen examined, $5(27.8 \%)$ were infected. The infection rate constitutes $16.7 \%$ of the total parasite encountered for fishes in pond and $50 \%$ of fishes in dam. Among the body parts of the sampled fishes from the pond, the gill $16.7 \%$ and fins $16.7 \%$ had the same percentage of parasite per location, while skin had $16.7 \%$ and also the intestine $33.3 \%$ had the highest percentage per location of the fish sampled from the dam. The collection comprises of different sizes of the total length, $19 \mathrm{~cm}-48 \mathrm{~cm}$ and also between $150-750 \mathrm{~g}$. Bigger fishes had more parasites than smaller ones. The ectoparasites encountered were found on the skin, fins and gills, whereas the small intestine was site for all the endoparasites recovered.
\end{abstract}

Keywords: Ectoparasites; Endoparasites; Clarias gariepinus; Bauchi metropolis; Nigeria

\section{Introduction}

Fish is a cheap and important source of protein and also contains calcium, lipids, minerals, vitamins and oils. The byproduct of fish can be incorporated into feeds of livestock and poultry. The most common fish available in Nigeria are the catfish species of Clarias gariepinus and Clarias angulus. They occur mainly in still water, lakes and pools but may also be found in fast flowing rivers [1]. They can also survive in dry season due to the possession of accessory breathing organ [2-3]. Fish is important to human populace in trade and economy and also in the diet of different countries especially the tropics and subtropics where malnutrition is a major problem.

In most part of the world, fish production is mainly from wild but as the population grows, fish resources are being depleted at an ever increasing rate as a result of environmental degradation, over harvesting and water pollution. Parasitic infections are some of the factors hindering high fish productivity in fish farming [4]. In many parts of the world, there exists a wide body of knowledge on fish parasites and diseases as evidenced by enormous amount of literature and information available.

\footnotetext{
${ }^{*}$ Corresponding author

E-mail address: ublessedchi@ yahoo.com

Copyright (C) 2018 Author(s) retain the copyright of this article. This article is published under the terms of the Creative Commons Attribution Liscense 4.0.
} 
Some fish parasite would develop in humans if the fish is eaten raw, but none would be harmful if the fish is cooked thoroughly. Parasites are one of the most diverse and common pathogens the agriculturist may likely encounter as parasitic disease are very common all over the world and are of particular importance in the tropics [5]. The parasite of fish can either be internal or external. The parasitic infection of fish gives an indication of the quality of water as they generally increase the abundance and diversity in more polluted water irrespective of the species, either through injury to the tissue organs in the process of burrowing or consuming food or the removal of digested food in the gut of the fish as well as the secretion of proteolytic enzymes.

The study of fish has therefore become very important since the parasites affect fish production directly by inducing stress and disease conditions in the fish. These diseases cause sluggish behavior, swirling, spiral or erratic movements, gill damage and white nodules on the gills.

This research therefore was conducted to find the parasites that militate against high production of fish in Bauchi, Bauchi State. It also compared the rates of parasitic infection among different types of fish cultivation farm (Dam, plastic and concrete ponds) in the study area.

\section{Material and methods}

\subsection{The location of the study areas}

The study was conducted in three areas in Bauchi metropolis. Bauchi is located between Latitudes $9^{\circ} 3^{\prime}$ and $12^{\circ} 3^{\prime}$ North of the Equator and Longitudes $8^{\circ} 5^{\prime}$ and $11^{\circ}$ East of Greenwich Meridian. The Dam, which is a natural habitat for uncultivated fish, is located in the Gubi village, outskirts of Bauchi town. The two ponds are KEAN farm and Bauchi State Agricultural Development (BSADP) farm. The KEAN farm is a plastic pond in which fish is cultivated by an individual enterprise. The BSADP farm is a concrete pond manned by the Bauchi State ministry of Agriculture. The two ponds are located in the Bauchi Township.

\subsection{Sample collection and treatment}

A total of eighteen samples of Clarias gariepinus of various sizes were purchased from the local fishermen between 7:00 am and 9:00 am. The samples were then transported to the laboratory, Department of Biological Sciences, Abubakar Tafawa Balewa University, Bauchi in plastic buckets containing the dam water for life specimens and Ice Park for dead ones to avoid distortion and to enhance recovery of the parasite.

\subsection{Measurement}

The total and standard length of each fish was measured using a meter rule. The length is defined as the length of the fish from the top of the snout to the end of the caudal fin while the standard length is the distance between the top of the snout and the caudal peduncle. The weights of the fish were measured in gram using electronic meter balance.

\subsection{Parasitological technique}

Appropriate parasitological technique was employed for examination of sampled fish for parasitic organism. Various methods were employed in the examination of the fish specimens for parasite after satisfactory routines [6-9]. In the examination for parasitic infection, special attention was paid to various locations which include the gills, skins, fins and walls of the intestine and stomach.

\subsection{Examination for ecto-parasite}

External examination of each of the fish for parasite was carried out using technique of Emere and Egbe [10] on the skin, gills and fins. The skin, gills and fins were also examined for ectoparasite using hand lens. The samples were cutted using scalpel blade. The tissue was placed on a Petri dish and $3 \mathrm{ml}$ of $0.9 \%$ saline solution were added and stirred using a mounted pin. Some drops of mixed solution were collected using dropper, placed on a slide and covered with a cover slip after which observation was made on light microscope. The gills of each of the fish were dissected using a dissecting kit. Each of the gills was placed in $10 \mathrm{ml}$ of normal saline into the Petri dish and later removed and then placed on a slide on which 1-2 drops of saline was added and observed on a binocular microscope. External examination using hand lens for large crustaceans and lesions on skin and fin was employed and the observations noted. 


\subsection{Examination for endo-parasite}

The stomach and intestine of each fish were cut opened and the contents washed into Petri dishes containing saline solution. The lining of the gut lumen was also scraped out and placed in the solution. 1-2 drops of the preparation was placed on the slide covered with cover slip and observed using light binocular microscope for endoparasite. The emergence of any parasite was easily noticed by its wriggling movement in the saline solution under the microscope. The parasites were identified by comparing with the pictoral guide on fish parasite [11]. Identification of specimens to species level were undertaken and confirmed following the methods of Oniye et al [12] and Akinsanya and Otunbayo [13].

\section{Results}

Out of the total of 18 fishes examined ( 6 from the dam, and 6 from each of the ponds), 5 representing $27.8 \%$ were infected with one parasite or another. The dam recorded the highest infection rate of 50\%, while the ponds recorded $16.7 \%$ each (see Fig. 1). Chi-Square analysis showed no significant difference among the infection rates of the different sampling sites $(\mathrm{P}>0.05)$. Out of the samples from the Gubi dam, 16.7\% was infected with Ichthyopthirus multifiliis, an ectoparasite found on the skin, $16.7 \%$ was infected with Diphylobothrium dendriticum, an endoparasite found in the gut and $16.7 \%$ was also infected with D. latum, an endoparasite found also in the gut (see Table 1). The pattern of infection of samples from the Dam showed ectoparasite with 16.7\% while endoparasites with 33.3\%.

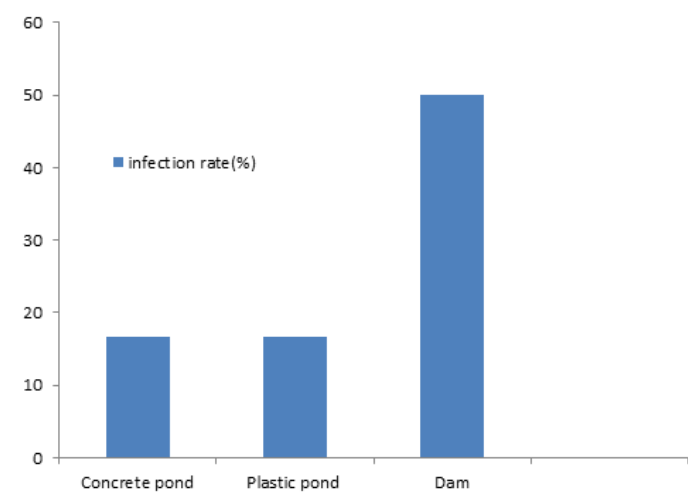

Figure 1 Infection rates of the samples from the different sampling areas

Table 1 Parasites found in the samples from the Dam at different microhabitats

\begin{tabular}{lll}
\hline Parasite & $\begin{array}{l}\text { No of fish infected by } \\
\text { each parasite (\%) }\end{array}$ & $\begin{array}{l}\text { Location of parasite } \\
\text { (Microhabitat) }\end{array}$ \\
\hline Ichthyopthirus multifiliis & $1(16.7)$ & Skin \\
Diphyllobothrium dendriticum & $1(16.7)$ & Small intestine \\
Diphyllobothrium latum & $1(16.7)$ & Small intestine \\
\hline
\end{tabular}

The infection rates found in the samples from the ponds are $16.7 \%$ in the KEAN farm (Plastic pond) and also $16.7 \%$ in the BSADP farm (Concrete pond). The parasites encountered are I. mutifiliis, an ectoparasite found at the gills and Trichodinasp., an ectoparasite found at the fins (see Table 2).

Table 2 Parasites found in the samples from the two ponds at different microhabitats

\begin{tabular}{llll}
\hline Parasite & $\begin{array}{l}\text { No. of parasite } \\
\text { in concrete pond (\%) }\end{array}$ & $\begin{array}{l}\text { No. of parasite } \\
\text { in plastic pond (\%) }\end{array}$ & $\begin{array}{l}\text { Location of parasite } \\
\text { (Microhabitat) }\end{array}$ \\
\hline Ichthyopthirus multifiliis & $0(0)$ & $1(16.7)$ & Gill \\
\hline Trichodina sp & $1(16.7)$ & $0(0)$ & Fin \\
\hline
\end{tabular}




\section{Discussion}

Different kinds of parasites were observed to be present in different microhabitats in C. gariepinus. Ichthyopthirius muftifilis occurred on the gill and skin, Trichodina sp. was found on the fins and Diphyllobotrium latum and Diphyllobotrium dendriticum were found on the small intestine. Other reseachers had reported the infection of the skin, fin and gills by the same parasite [10,14-15].

Ichthyopthirius muftifilis caused erosion of the epithelium and thickening of the gills and could be attributed to inflammatory process which occurred during infection with these parasitic ciliates as described by Sigh et al., [16]. Trichodina sp. Infection also caused removal of epithelium and excess mucus production which result in covering of the infected fins and gills with thick layer of mucus. This agrees with some earlier works [17], which also reported that most parasites inhabit the intestine because of the acidic nature of the small intestine. Most parasites in the alimentary canal of fish are pathogenic. The pathological effects are as a result of mechanical damage that is caused by the organs of attachment.

The infection rates of Fish from concrete pond (16.7\%), and plastic pond (16.7\%), is low compared to that of dam samples (50\%). This would appear to be associated with several activities going on in the dam water which may enhance the chance of fish to come in contact with infections. It is noted that the parasites in the present study were restricted to few anatomical sites like the skin, fins gills and small intestine. This localization may be ascribed to several factors including food reserves, chemotactic response and hydrogen ions $\left(\mathrm{H}^{+}\right)$concentrations. The small intestine, as a microhabitat, had the highest parasite density among all the microhabitat sites. The ecto-parasites encountered were on the skin, gills and fins whereas the small intestine was the most favored site for endo-parasite.

\section{Conclusion}

The study has revealed that Clarias gariepinus present in Gubi dam and fish ponds in Bauchi harbors various types of parasites some of which are highly pathogenic. Efforts should therefore be geared towards their control. By so doing, fish production in the area will in no doubt enhance the supply of protein in Bauchi metropolis in particular and Nigeria at large.

\section{Compliance with ethical standards}

\section{Acknowledgments}

The authors thank the Managements of KEAN and Bauchi State Agricultural Development (BSADP) farms for allowing us to collect samples from their farms for this work. The support of the Laboratory Technologists of the Biological Sciences Department, Abubakar Tafawa Balewa University Bauchi is also appreciated.

\section{Disclosure of conflict of interest}

The authors declare no conflict of interest of any form.

\section{References}

[1] Ayanda OI. (2009). Comparison of parasitic helminthes infection between the sexes of Clarias gariepinus from Asa dam Ilorin, north-central, Nigeria. Scientific Research and Essay 4(4), 357-360.

[2] Ovie SI and Ovie SO. (2002). Fish larval rearing: the effect of pure/mixed Zooplankton and artificial diet on survival of Clarias angularis larvae. Journal of Aquatic Science 17(1), 67-73

[3] Hofman LCand Prinsloo JF. (1996). The potential of freshwater fish in South Africa. Food Industries of South Africa, 30, 1-2.

[4] Kayis S, Ozcelep T, Capkin E and Altinok I. (2009). Protozoan and metazoan parasites of cultured fish in Turkey and their applied treatments. Israeli Journal of Aquaculture-Bamidgeh, 2(61), 93-102.

[5] Roberts LS and Janovy J. (2010). Gerald D Schmidt and Larry S. Roberts' Foundations of Parasitology. McGrawHill, Boston, USA, McGraw-Hill International Edition, 701. 
[6] Biu AA, Diyaware MY, Yakaka W and Rita DJ (2014). Incidence of parasites of Clarias gariepinus (Burchell, 1822) caught from lake Alau, Maiduguri, Borno State, Nigeria. Nigerian Journal of Fisheries and Aquaculture, 2(1), 74 80 .

[7] Bichi AH and Yelwa SI. (2010). Incidence of piscine parasites on the gills and gastrointestinal tract of Clariasgariepinus (Teugels) at Bagauda Farm, Kano. Bayero Journal of Pure and Applied Science, 3(1), $104-107$.

[8] Bichi AH and Dawaki SS. (2010). A survey of ectoparasites on gills, skin and fins of Oreochro misniloticus at Bagauda Farm, Kano. Bayero Journal of Pure and Applied Science, 3(1), 83 - 86.

[9] Olurin KB and Somorin CA (2006). Intestinal helminthes of the fishes of Owastream, South West Nigeria. Research Journal of Aquatic Science, 19(2), 71- 76.

[10] Emere MC and Egbe NEL. (2006). Protozoan parasites of Synodonits clarias (a fresh water fish in river Kaduna). BEST Journal, 3(3), 58-64.

[11] Pouder DB, Curtis EW and Yanong RP. (2005). Common freshwater parasite pictorial guide edis, http://edis.ifas.ufl.edu/.

[12] Oniye SJ, Adebote DA and Ayanda OI. (2004). Helminth parasites of Clarias gariepinusin Zaria. Nigeria Journal of Aquatic Sciences 19(2), 71-76.

[13] Akinsanya B and Otubanjo OA. (2006). Helminth parasites of Clarias gariepinus (Clariidae) in Lekki Lagoon, Lagos, Nigeria. Revista de BiologiaTropical, 54(1), 93-99.

[14] Olofintoye LK. (2006). Parasitofauna in some freshwater fish species in Ekiti State, Nigeria. Pakistan Journal of Nutrition, 5(4), 359-362.

[15] Nnadi EI. (2012). A study of parasitic infections of Clarias gariepinus in natural waters of Owerri, imo State, Nigeria. International Journal of Agriculture and Rural Development 15(2), 976- 981.

[16] Sigh J, Lindenstrøm, T and Buchmann K. (2004). Expression of pro-inflammatory cytokines in rainbow trout (Oncorhynchus mykiss) during an infection with Ichthyophthirius multifiliis. Fish and Shellfish Immunology. 1(17), 75-86.

[17] Obiekezie A and Ekanem D. (1995). Experimental infection of Heterobranchus longifilis (Teleostei, Clariidae) with Trichodina maritinkae (Ciliophora, Peritrichida). Aquatic Living Resources, 8, 439-443.

\section{How to cite this article}

Udechukwu CU, Panda SM, Sunday ID and Bello FA. (2018). Parasites associated with Clarias gariepinus (African catfish) from dam, plastic and concrete ponds in Bauchi metropolis, Bauchi State, Nigeria. GSC Biological and Pharmaceutical Sciences, 2(2), 01-05. 